\title{
Impact of Brand Equity on Consumer Brand Preference and Brand Purchase Intention
}

\author{
Muhammad Adnan Bashir ${ }^{*}$ \\ Syed Muhammad Faheem ${ }^{2}$ \\ Masood Hassan ${ }^{3}$ \\ Waseem Akhtar Shaikh ${ }^{4}$
}

\begin{abstract}
Product differentiation has become a difficult task for the marketers because of the increasing number of brands in the market. It is also noted that, the product differentiation which gets it basis fromthe brand i.e. brand equity, turns out to be more effective than others. This is the reason why the marketers are emphasizing more on strengthening the brand equity of a brand. A conceptual framework was constructed to measure the impact brand equity has from all the other components under brand equity. Furthermore, consumer brand preference and consumer's brand purchase intention were also studied alongwith the effects of brand equity on them. The sample size was chosen 385 and it was quite responsive; only $5 \%$ of them did not respond. The prior studies were used in developing the constructs by making sure their applicability and validity in recent times. Likert scale was used in the questionnaire to get the answers from respondents. The data was collected on basis of convenience sampling. Model was analyzed completely after conducting the preliminary analysis. Then hypotheses were analyzed on basis of regression which ruled out only one out of seven.
\end{abstract}

Keywords: Brand Equity, Perceived Sales Promotion Intensity, Uniqueness, Brand Attitude

1- Assistant Professor at IoBM, Institute of Business Management, email: adnan.bashir@iobm. edu.pk

2- Assistant Professor IoBM

3- Senior Lecturer IoBM

4-Lecturer-Department of Mangement Sciences, ILMA University,waseemskh.11@gmail.com 


\section{INTRODUCTION:}

Brand equity is among the most studied concepts in marketing literature (Datta Hans, 2017). Firms invest with lot of resources tounderstand and build strong brand equity (Builet al., 2013), which ultimately influences brand preference of the consumer and the purchase intention (Moradi \& Zarei, 2011; Tolba \& Hassan, 2009; Chang et al., 2008; Chen \& Chang, 2008). Consumers favor strong brands as the decision reduces product related risk and failure, eliminates uncertainty about the product choice, and consumer enjoys emotional and social benefits from the chosen brand (Fischer,Vo"lckner, and Sattler 2010). Brands having strong brand equity hold certain edges like, evaluated positively by customers, receive selective attention, included in final consideration set, and it also increase the probability to be chosen at point of purchase i.e. final point of contact between customer and brand (Hoeffler and Keller 2003).Concept of brand equity was developed in 1980s. Two famous explanations (models) related to brand equity come from Aaker (1991) as well as Keller (1993).

Intanglible assets and liabilities sum up the brand equity (Aaker, 1991), the value is added from the assets whereas, and the brand is devalued from the liabilities. There are four major components Aaker's brand equity model i.e.perceived quality, brand awareness, brand loyalty, and brand association. For study, we are taking brand equity model by Aaker.

Rich literature is available on antecedents \& consequences of brand equity. Academic literature provides the evidence of studying brand equity with several dimensions; concept building and explanation (Aaker, 1991; Keller, 1993); impact of marketing expenses on brand equity (Stahletal.2012; Sriram, Balachander, and Kalwani 2007); factors that contribute in leveraging brand equity into brand extension (Bottomley and Holden 2001; Batra, Lehmann, and Singh 1993); brand equity outcomes related to product and market i.e. price and revenue premiums, market share and profit premiums (Goldfarb, Lu, and Moorthy 2009; Srinivasan, Park, and Chang 2005; Ailawadi, Lehmann, and Neslin 2003); the brand equity's outcomes related to financial market ends i.e. returns, risks, and market value (Rego, Billett, and Morgan 2009; Mizik and Jacobson 2008).

Brand equity resides in the heart and mind of customers, and clearly impacts on a consumer brand preference and consumer's purchase intention (Vinh \& Huy, 2016; Moradi \& Zarei, 2011; Tolba \& Hassan, 2009; Chang et al., 2008). Now days, market is saturated with hundreds of alike brands, and product differentiation has become difficult. Differentiation based on strong brand equity lasts longer than differentiation based on physical features. Hence, organizations for brand differentiation focused to create brand equity (Keller, 2009). The twofold goals of the study are I) measuring the impact of constituents of brand equity on the brand equity as a whole, II) measuring the impact of brand equity on consumer brand preference and consumer purchase intention.

\section{LITERATURE REVIEW:}

\section{Brand Equity}

The field of marketing has been overtaken a lot by the theme of brand equity (Saydan, 2013). There are two in ways in which one can go through the literature of brand equity; i.e. the customer-based perspective and the financial one (Keller, 1993; Chaudhuri, 1995; Chang et al., 2008). The latter perspective of brand equity supports that the brand equity is financial asset value which is endorsed and treated accordingly by the brands or the producers (Lassar et al., 1995; Chang \& Liu, 2009) which means the worth of a brand name adds up in a product or a service (Chaudhuri, 1995). As per 
Aaker (1991, p. 15) the concept of brand equity is, "a set of brand assets and liabilities linked to a brand, its name and symbol that add to or subtract from the value provided by a product or service to a firm and/or to firm's customers". Similarly Keller states that (1993, p. 2), it is "the differential effect of brand knowledge on consumer response to the marketing of the brand". If we compare two mentioned perspectives of brand equity with each other, we come across numerous scholarly supporters for the brand equity based on customers' perspective. Other definitions will not be of any use if proper denotation is not considered by the brand for the customer (Cobb-Walgren et al., 1995). Hence, theresearch centered round the customer-based perspective. Following conceptual framework was proposed.

\section{Conceptual framework}

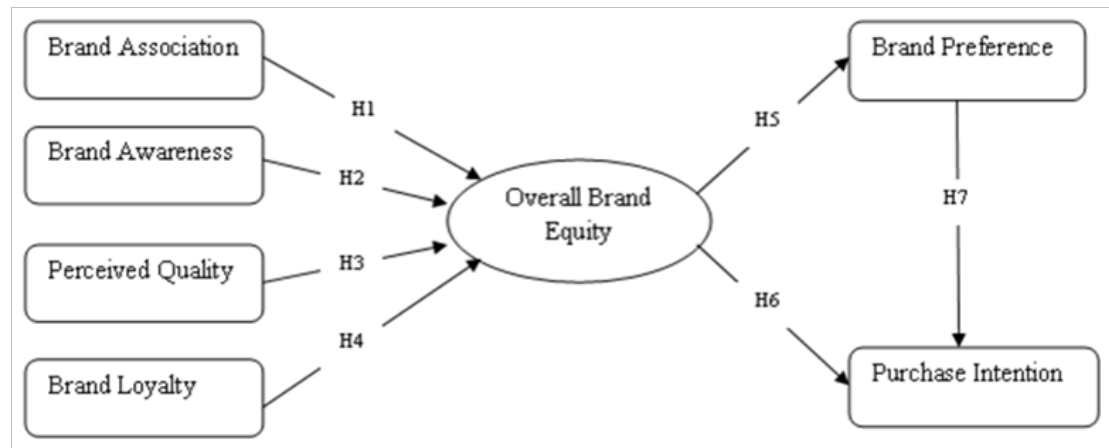

\section{Elements of Brand Equity}

There are many dimensions which are considered for brand equity; However, Aaker (1991) chose to consider five dimensions of brand equity i.e. brand loyalty, brand association, perceived quality, brand awareness, and other proprietary brand assets. Rest of the proprietary brand assets are not much considered during the research analysis because they do not have a direct relationship with the consumers (Saydan, 2013).

\section{Brand Associations:}

"Anything linked in memory to a brand" is brand association (Aaker, 1991). Brand association is considered an important aspect in the composition and handling of brand equity by Rio et al. (2001). This means that a good link of customer with the brand comes with high brand equity. Aaker (1991) presented that the firm and its consumers could get value through brand associations bypresenting a positive image of the brand, making it prominent and different from other brands and giving valid reasons to the customer to opt for this brand as compared to others. When there is enough understanding with the customer for brand and it has strong connection with it, customer brandequity is generated. (Tong \& Hawley, 2009).

\section{Brand Awareness:}

"The ability of the potential buyer to recognize and recall that a brand is a member of a certain product category" is brand awareness (Aaker, 1991, p. 61). It is also one of the essential components of brand equity. This is the first and foremost level of developing brand equity (Buil et al., 2013b). Precondition for both the brand and customer-based equity is the awareness. The level of awareness a customer has helps a lot in shaping up the brand equity (Jalilvand et al., 2011). It helps in making the customers familiar with the brand (Aaker, 1991); which affects the brand positively. 


\section{Brand Loyalty:}

"A deeply held commitment to re-buy or re-patronize a preferred product or service consistently in the future, despite situational influences and marketing efforts having the potential to cause switching behavior" is what considered brand loyalty by Oliver (1997, p. 392). The key element of brand equity is assumed to be brand loyalty. It forces the customer to opt for the particular brand over and over again out of habit instead of choosing someone else's products (Yoo et al., 2000). Aaker (1991) believes that brand loyalty is highly essential in value addition in a brand since it gives brand loyal customers for a longer period of time. Most of the positive responses are from the loyal customers (Grover \& Srinivasan, 1992). Also, the loyal customer did not let the brand go just because of the pricing; they are also frequent buyers of the brand as compared to the non-loyal customers. Hence, brand loyalty plays a crucial role in brand equity.

\section{Perceived Quality:}

According to Zeithaml (1988), "The consumer's judgment about a product's overall excellence or superiority"is perceived quality. It is believed to be "core" dimension of the brand equity. It helps in value addition of a brand in a number of ways. Perceived quality helps in determining the changes in price, reasoning for choosing a particular brand, and reasoning for having brand extension too (Aaker, 1991; Saydan, 2013). According to the concept of high perceived quality, which supports the concept that the customer recognizes the brand and its differentiation due its experience (Yooet al., 2000); this is the reason why perceived quality and brand equity are directly proportional to each other (Yoo et al., 2000; Buil et al., 2013b).

\section{Brand Equity and Brand Preference:}

Numerous writers have claimed that brand equity is quite important for any brand, which helps in customer brand preference (Chang et al., 2008). Many research papers recognize the importance of brand equity when it comes about customers' decision making in preferring a brand for himself (Hoeffler \& Keller, 2003). A lot of studies also claim brand preference has a great impact of brand equity on it. When Myers (2003) did a research to learn about the relationship between the two through soft drinks, the research came up with a conclusion that there is a very strong relationship between both of them. Similarly, Buil et al. (2013b) also did a research in three product categories and concluded with the same result. Many other studies conducted by various researchers came up with the conclusion that there is a very immediate and well-builtconnection between high brand preference and high brand equity.

\section{Brand Equity and Purchase Intent:}

There is also an immediate link between purchase intent and brand equity which is backed up by many researches. When Cobb-Walgren et al. (1995) did a research to know more about the relation between these two by using two different brands in the study, he concluded that those brands who had a strong brand equity influenced and made more purchase intents. Likewise, conclusions from different researches (e.g. Chen \& Chang, 2008; Chang \& Liu, 2009; Moradi \& Zarei, 2011) also showed that brand equity influences purchase intent.

\section{Brand Preference and Purchase Intent:}

As the theory of reasoned action recognized the relationship of the behavior, attitudes, and intention (Fishbein \& Ajzen, 1975); similarly, a supportive attitude for a brand directs to the purchase intention (Builet al., 2013b). Since Cobb-Walgren et al. (1995) claimed that there is a strong link between the brand equity and purchase intent; and brand equity reflects brand preference too, so it can also be claimed that brand preference and purchase intent are related likewise. The researches 
IBT Journal of Business Studies Volume 15(1), 2019

also suggested that there is a positive relationship between the two (e.g. Chen \& Chang, 2008; Chang \& Liu, 2009; Tolba \& Hassan, 2009; Moradi \& Zarei, 2011).

\section{Hypotheses:}

Brand associations significantly affect overall brand equity. (H1)

Brand awareness significantly influence on the overall brand equity. (H2)

Perceived quality of brand a significantly influence on the overall brand equity. (H3)

Brand Loyalty significantly influence on the overall brand equity. (H4)

Brand equity significantly influence on the preference of brand. (H5)

Brand equity significantly influence on the brand purchase intention. (H6)

Brand preference significantly influence on the brand purchase intentions. (H7)

\section{METHODOLOGY}

Primary data was gathered from the respondentsfor working on the selected study. Questionnaires were developed for collecting the relevant data from the respondents and all the questions were based on likert scale. The items were created by considering the prior researches. Different measures were used to study each and every construct in the study. Targeted population for the study was the general consumers of Karachi. Data gathered through convenience sampling. 400 questionnaires distributed in five different business schools at Karachi. After screening, the questionnaire 385 responses were able to be used in further research. Univariate normality established through skewness and kurtosis. Cronbach's alpha and Composite Reliability (CR) used as reliability measures. Construct reliability established through convergent and discriminant validity. Finally model (SEM) was tested for goodness of fit on AMOS. Among techniques of statistical modeling SEM is recognized as the youngest for the purpose of regression analysis (Siddiqui, Mirani \& Fahim, 2015).

Further elaborated study of the scale items' is in table 1.

Table: 1

\begin{tabular}{|c|c|c|c|}
\hline 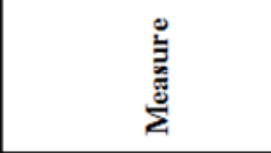 & 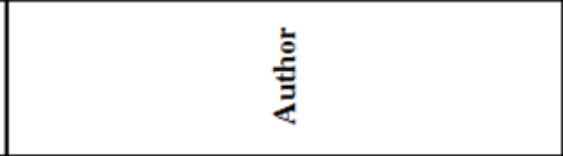 & 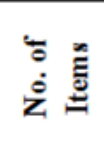 & 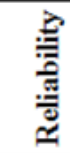 \\
\hline Perceived Quality & Pappu et al . (2005, 2006) & 4 & 0.92 \\
\hline Brand Awareness & Yoo et al. (2000); Netemeyer et al. (2004) & 5 & 0.9 \\
\hline Brand Association & Pappu et al . (2005, 2006) & 4 & 0.92 \\
\hline Brand Loyalty & Yoo et al. (2000) & 3 & 0.9 \\
\hline Overall Brand Equity & Yoo et al. (2000) & 3 & 0.87 \\
\hline Brand Preference & Chen andChang (2008) & 3 & 0.76 \\
\hline Purchase Intention & Cronin et al. (2000), & 3 & 0.74 \\
\hline
\end{tabular}




\section{RESULTS}

\section{Descriptive Statistics}

Univariate normality of the constructs established through descriptive statistics. Table 2 contains summarized results.

\begin{tabular}{|l|l|l|l|l|}
\hline Construct & Mean & Std. Dev & Skewness & Kurtosis \\
\hline Perceived Quality & 3.90 & 1.44 & -.027 & -.838 \\
\hline Brand Awareness & 3.92 & 1.31 & -.067 & -.598 \\
\hline Brand Association & 3.40 & 1.40 & .358 & -.485 \\
\hline Brand Loyalty & 3.91 & 1.40 & .040 & -.531 \\
\hline Overall Brand Equity & 4.67 & 1.51 & -.461 & -.553 \\
\hline Brand Preference & 3.46 & 1.36 & -.037 & -.825 \\
\hline Purchase Intention & 4.27 & 1.46 & -.298 & -.553 \\
\hline
\end{tabular}

According to Table 2, brand awareness (Mean=3.92, $\mathrm{SD}=1.31)$ is least skewed $(-0.06)$, and brand association (Mean $=3.40, \mathrm{SD}=1.40$ ) has the highest Skewness (0.358). Additionally perceived quality (Mean $=3.90, \mathrm{SD}=1.44$ ) has the highest kurtosis (-.838) and brand association (Mean=3.40, $\mathrm{SD}=1.40)$ has the lowest kurtosis $(-.485)$. The skewness and kurtosis values are ranged between \pm 3.5 ; hence, data fulfills the univariate normality requirements (Haier 2007).

\section{Reliability, Validity and Correlation}

To establish validity and reliability of measures with multi item scales different techniques were adopted. For reliability both Cronbach alpha $(\alpha)$ and composite reliability $(C R)$ were used. EFA and CFA were performed to establish validity and average variance extracted (AVE).

Table 3.

Reliability and Validity

\begin{tabular}{|l|l|l|l|l|l|l|l|l|l|l|}
\hline Construct & $\alpha$ & CR & AVE & PQ & BAW & BA & BL & OBE & BP & PI \\
\hline Perceived Quality & .89 & .68 & .79 & .87 & & & & & & \\
\hline Brand Awareness & .74 & .37 & .32 & .40 & .70 & & & & & \\
\hline Brand Association & .72 & .66 & .87 & .32 & .26 & .74 & & & & \\
\hline Brand Loyalty & .87 & .54 & .82 & .25 & .21 & .28 & .88 & & & \\
\hline Overall Brand Equity & .82 & .61 & .86 & .10 & .10 & .05 & .06 & .85 & & \\
\hline Brand Preference & .87 & .70 & .87 & .35 & .25 & .28 & .34 & .05 & .89 & \\
\hline Purchase Intention & .89 & .75 & .73 & .12 & .06 & .12 & .12 & .07 & .24 & .91 \\
\hline
\end{tabular}

The square root of variance explained is bold and italic (Diagonal) 
IBT Journal of Business Studies Volume 15(1), 2019

The table 3 shows that the reliably of all constructs greater than 0.70 , and it ranges between 0.72 to 0.89 and shows good internal consistency (W. Zikmund, Babin, Carr, \& Griffin, 2012). Validity of the constructs established through convergent and discriminant validity (fieldman 2010). All the factor loadings and variance explained except brand awareness are greater than 0.60 , convergent validity's requirement were met by the data (Bryman $\&$ Bell, 2011). As Square root $(\sqrt{ })$ of variance showed of each construct exceed the each correlation pair endorsing discriminant validity requirements of constructs claimed by Fornell \& Larcker (1981) andHair Jr et al.(2006).

\section{Testing of Overall Model}

For testing our hypotheses and working for establishing a good model we used SEM in AMOS 21. The model was found to be a good fit, according to the results. 3.63 was cmin/df, 0.92 was the GFI value, 0.92 was CFI value, and 0.05 was RMSEA value. The overall values of the model fit are presented in table 4 .

Table 4.

Overall Model Fit Values

\begin{tabular}{|l|l|l|l|l|l|l|l|l|l|l|}
\hline Construct & Absolute & Relative & Parsimonious & & & & & & & \\
\hline & $\chi 2$ & $\chi 2 / \mathrm{df}$ & DOF(p) & GFI & AGFI & CFI & NFI & IFI & PNFI & PCFI \\
\hline Overall Model & 2117 & 3.63 & $77(.000)$ & .92 & .87 & .92 & .90 & .92 & .66 & .68 \\
\hline Criteria & Low & $<5.0$ & $\mathrm{n} / \mathrm{a}$ & $>.90$ & $>.90$ & $>.90$ & $>.90$ & $>.90$ & $>.50$ & $>.50$ \\
\hline
\end{tabular}

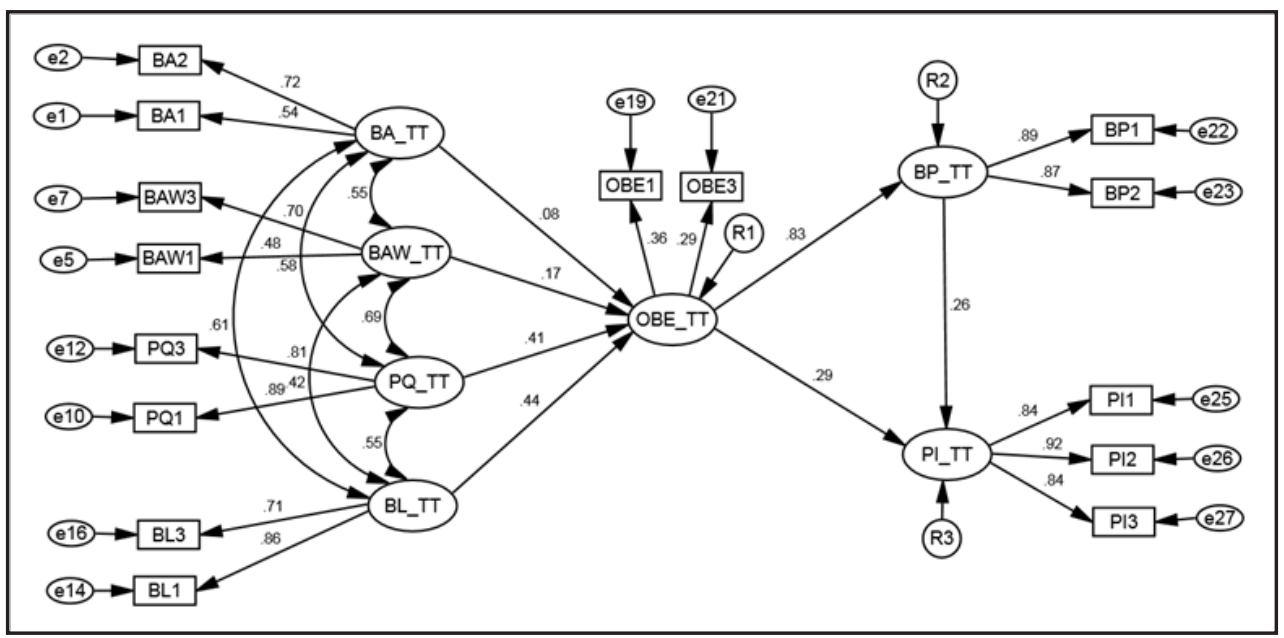

Figure 2.

SEM model

\section{Hypotheses Results}

Seven hypotheses were developed in total, in which only one was unacceptable. Overall brand equity is strongly predicting (SRW was 0.83 ) brand preference followed by brand loyalty (SRW was 0.44 ) to overall brand equity. There was not any strong influence found of brand association on overall brand equity, hence rejecting H1 (SRW was 0.08 , CR was 0.811 , P was $0.418>0.05$ ). 
Overall brand equity showed to positively influenced by brand awareness, perceived quality, and brand loyalty which supported H2 (SRW was 0.17 , CR was 1.573 , P was $0.001<0.05$ ), H3 (SRW was 0.41 , CR was 3.736, P was $0.001<0.05$ ), and H4 (SRW was 0.44 , CR was 4.353, P was 0.001 $<0.05)$ respectively.

Similarly, brand equity had a good and positive impact on consumer brand preference and purchase intention, which supported H5 (SRW was 0.83, CR was 6.740, P was $0.001<0.05$ ) and H6 (SRW was 0.29 , CR was 2.026 , P was $0.001<0.05$ ). Finally, consumer brand preference showed to positively impact consumer purchase intention, which supported H7 (SRW was 0.25, CR was 1.884, $\mathrm{P}$ was $0.001<0.05)$. Table 5 presents the summary of statistical values related to test the hypotheses.

Table 5.

Results of Hypotheses

\begin{tabular}{|c|c|c|c|c|c|c|c|}
\hline \multicolumn{3}{|c|}{ Relationships } & SRW & SE & $\mathrm{CR}$ & P Value & Results \\
\hline Overall Brand Equity & $<---$ & Brand Association & 0.08 & 0.067 & 0.811 & 0.418 & Rejected \\
\hline Overall Brand Equity & $<---$ & Brand Awareness & 0.17 & 0.08 & 1.573 & $* * *$ & Accepted \\
\hline Overall Brand Equity & $<---$ & Perceived Quality & 0.41 & 0.048 & 3.736 & $* * *$ & Accepted \\
\hline Overall Brand Equity & $<---$ & Brand Loyalty & 0.44 & 0.039 & 4.353 & $* * *$ & Accepted \\
\hline Brand Preference & $<---$ & Overall Brand Equity & 0.83 & 0.296 & 6.74 & $* * *$ & Accepted \\
\hline Purchase Intention & $<--$ & Overall Brand Equity & 0.29 & 0.347 & 2.026 & $* * *$ & Accepted \\
\hline Purchase Intention & $<---$ & Brand Preference & 0.25 & 0.137 & 1.884 & $* * *$ & Accepted \\
\hline
\end{tabular}

\section{Summary \& Discussion}

The study was conducted for measuring impact of brand equity elements on the overall brand equity, $\&$ consequently does overall brand equity influence on consumer brand preference and purchase intention. There were seven hypotheses in total in which six were acceptable.

It is evident from the results that overall brand equity is under the positive influence of its elements i.e. brand awareness, perceived quality, and brand loyalty. Findings of the research are consistent to previous researches. Brand awareness shows the level of customer's knowledge regarding brand i.e. what is brand?, for what purpose the brand is?, and how it works etc. It generally condidered as the the most initial level in the compostion of brand equity (Buil et al., 2013). When a consumer becomes aware of the brand, it sets a quality level in his mind which ultimately influence brand equity (Jalilvand et al., 2011). Perceived quality is the image of the quality of the brandacccording to the customer. It also considered as a strong predictor of brand equity. It affects brand valu in certain ways e.g. it is a strong cue for consumer to select the brand. Organizations by setting the perceiveq quality on a good level can charge higher prices and earn good profits. Similarly it provides a stong reason to organizations for brand extension (Saydan, 2013). Brand loyalty considered highly essenial element of the brand equity. Strong brand loyalty prevents the customer from opting for any other brand (Yoo et al., 2000). Loyal customers are also a good source for word of mouth activity. Loyal customers when share their feelings, and experiences regarding the product on social media it can produce marvelous results (Schivinski \& Dabrowski, 2015). Impact of brand association on overall brand equity was not much noticeable and the findings are inconsistent to some previous 
findings (Tong \& Hawely, 2009; Saydan, 2013). Aaker (1991) claims that brand association are "anything linked in memory to a brand". One possible justification for insignificance could be that having an association of brand to someone or something is not necessary that brand will get fame in the marketplace.

Overall brand equity significantly influenced on consumer brand preference and purchase intention. Strong brand equity of a brand holds the benefit of more customer brand preference. The high brand equity is linked with high brand preference (Hoeffler \& Keller, 2003; Chang et al., 2008). Many empirical studies also verify the idea that brand equity significantly influence consumer brand preference in different contexts (Myers, 2003; Chang et al., 2008; Buil et al., 2013). The brand equity is also related positively with purchase intention. The brands with superior brand equity produce greater purchase intention (Chang \& Liu, 2009; Moradi \& Zarei, 2011). Finally, brand preference also drives the purchase intention of a brand. Brand preference creates a sort of brand ranking in consumer's mind and consequently consumer intentionally favors the brand on top of the mind (Tolba \& Hassan. 2009; Builet al., 2013). Theory of reasoned action also supports the idea that favorable attitude for a brand leads to purchase intent for the same (Buil et al., 2013).

\section{Implications, Limitations \& Future Research}

Giving conceptual insight how brand equity is influenced by its elements, and ultimately what is the impact of brand equity on consumer brand preference and brand purchase intention in this research. Brand equity is strongly predicting consumer brand preference; means if the organizations are good in maintaining superior brand equity, it will lead to strong brand preference, and favorable attitude of consumers for a brand drives it purchase intent to buy the same brand.

One major metropolitan city i.e. Karachi was selected for data and the respondents of research were students belonging tovariousinstitutes and aged 20-29, hence generalizability is limited. Future research can be stretched to other cities and other age group people. We used brand "J." as stimulus. Future research can be performed with other product categories and brand names. We have so many sub-cultures with the main culture and research in future can be stretched to learn about the influence of sub-culture on the same or different variables. The differences due to gender on selected variables can also be measured in any research in future.

\section{REFERENCES}

Aaker, D. (1991). Managing brand equity. Capitalizing on the value of a brand name. USA:Free Press.

Ailawadi, Kusum L., Donald R. Lehmann, and Scott A. Neslin (2003), "Revenue Premium as an Outcome Measure of Brand Equity,” Journal of Marketing, 67 (October), 1-17.

Batra, Rajeev, Donald R. Lehmann, and Dipinder Singh (1993), "The Brand Personality Component of Brand Goodwill: Some Antecedents and Consequences," in Brand Equity and Adver- tising, David A. Aaker and Alexander Biel, eds. Hillsdale, NJ: Lawrence Erlbaum Associates, 83-96.

Bottomley, Paul A., and Stephen J.S. Holden (2001), "Do We Really Know How Consumers Evaluate Brand Extensions: Empirical Generalizations Based on Secondary Analysis of Eight Studies," Journal of Marketing Research, 38 (November), 494-500.

Bryman, A., \& Bell, E. (2011). Business Research Methods 3e. Oxford University Press. Retrieved from https://books.google.com.pk/books?hl=en\&lr=\&id=YnCcAQAAQBAJ\&oi=fnd\&pg=PP 2\&ots=Iiqn-woD3F\&sig=UTY96B4wSxrkGaqEmGc3cUNW_zU

Buil, I., Martínez, E., \& de Chernatony, L. (2013). The influence of brand equity on consumer 
responses. Journal of Consumer Marketing, 30(1), 62-74.

Chang, H. H., Hsu, C. H., \& Chung, S. H. (2008). The antecedents and consequences of brand equity in service markets. Asia Pacific Management Review, 13(3), 601-624.

Chang, H. H., \& Liu, Y. M. (2009). The impact of brand equity on brand preference and purchase intentions in the service industries. The Service Industries Journal, 29(12), 1687-1706.

Chen, C. F., \& Chang, Y. Y. (2008). Airline brand equity, brand preference, and purchase intentionsThe moderating effects of switching costs. Journal of Air Transport Management, 14(1), 40-42.

Datta, H., Ailawadi, K. L., \& van Heerde, H. J. (2017). How well does consumer-based brand equity align with sales-based brand equity and marketing-mix response?. Journal of Marketing, 81(3), 1-20.

Fischer, Marc, Franziska Vo“ lckner, and Henrik Sattler (2010), "How Important Are Brands? A Cross-Category, Cross-Country Study," Journal of Marketing Research, 47 (October), 823-39.

Fortin, C., Feldman, D. E., Cheriet, F., \& Labelle, H. (2010). Validity of a quantitative clinical measurement tool of trunk posture in idiopathic scoliosis. Spine, 35(19), E988-E994.

Goldfarb, Avi, Qiang Lu, and Sridhar Moorthy (2009), "Measuring Brand Value in an Equilibrium Framework," Marketing Science,28 (1), 69-86.

Hair, J. F., Black, W. C., Babin, B. J., Anderson, R. E., Tatham, R. L., \& others. (2006). Multivariate data analysis (Vol. 6). Pearson Prentice Hall Upper Saddle River, NJ. Retrieved from http:// library.wur.nl/WebQuery/clc/1809603

Hair, J. F. (2007). Research methods for business. Retrieved from http://digitalcommons.kennesaw. edu/facpubs/2952/

Hoeffler, Steven, and Kevin Lane Keller (2003), "The Marketing Advantages of Strong Brands," Journal of Brand Management, 10 (6), 421-45.

Jalilvand, M. R., Samiei, N., \& Mahdavinia, S. H. (2011). The effect of brand equity components on purchase intention: An application of Aaker's model in the automobile industry. International business and management, 2(2), 149-158.

Keller, K. L. (1993). Conceptualizing, measuring, and managing customer-based brandequity. The Journal of Marketing, 57(1), 1-22.

Mizik, Natalie, and Robert Jacobson (2008), "The Financial ValueImpact of Perceptual Brand Attributes," Journal of Marketing Research, 45 (February), 15-32.

Moradi, H., \& Zarei, A. (2011). The impact of brand equity on purchase intention and brand preference-the moderating effects of country of origin image. Australian Journal of Basic and Applied Sciences, 5(3), 539-545.

Myers, C. A. (2003). Managing brand equity: a look at the impact of attributes. Journal of Product \& Brand Management, 12(1), 39-51.

Rego, Lopo L., Matthew T. Billett, and Neil A. Morgan (2009), "Consumer-Based Brand Equity and Firm Risk," Journal of Marketing, 73 (November), 47-60.

Saunders, M., Lewis, P., \& Thornhill, A. (2003). Research methods for business students.

Saydan, R. (2013). Relationship between Country of Origin Image and Brand Equity: Empirical Evidence in the English Market. International Journal of Business and Social Science, 4(3).7888.

Schivinski, B., \& Dabrowski, D. (2015). The impact of brand communication on brand equity through Facebook. Journal of Research in Interactive Marketing, 9(1), 31-53.

Siddiqui, K. A., Mirani, M. A., \& Fahim, S. M. (2015). Model generation using structural equation modeling. Journal of Scientific Research and Development, 2(10), 112-116.

Srinivasan, V., Chan Su Park, and Dae Ryun Chang (2005), "An Approach to the Measurement, Analysis, and Prediction of Brand Equity and its Sources," Management Science, 51 (9), 143348. 
IBT Journal of Business Studies Volume 15(1), 2019

Sriram, S., Subramanian Balachander, and Manohar U. Kalwani (2007), "Monitoring the Dynamics of Brand Equity Using Store-Level Data,” Journal of Marketing, 71 (April), 61-78.

Stahl, Florian, Mark Heitmann, Donald R. Lehmann, and Scott A.Neslin (2012), "The Impact of Brand Equity on Customer Acquisition, Retention, and Profit Margin," Journal of Marketing, 76 (4), 44-63.

Tolba, A. H., \& Hassan, S. S. (2009). Linking customer-based brand equity with brand market performance: a managerial approach. Journal of Product \& Brand Management, 18(5), 356366.

Tong, X., \& Hawley, J. M. (2009). Measuring customer-based brand equity: empirical evidence from the sportswear market in China. Journal of Product \& Brand Management, 18(4), 262271.

Vinh, T. T. (2016). The relationships among brand equity, brand preference, and purchase intention: empirical evidence from the motorbike market in Vietnam. International Journal of Economics and Finance, 8(3), 75.

Yoo, B., Donthu, N., \& Lee, S. (2000). An examination of selected marketing mix elements and brand equity. Journal of the Academy of Marketing Science, 28(2), 195-211.

Zikmund, W., Babin, B., Carr, J., \& Griffin, M. (2012). Business research methods. Cengage Learning. Retrieved from https://books.google.com.pk/ 